\title{
ANALYSIS OF ELEMENTS AND PROCESS OF SCHOOL PRINCIPALS' PROFESSIONALIZATION IN CROATIA*
}

\author{
Renata Relja** \\ Toni Popovic ${ }^{* * *}$ \\ Tea Gutović ${ }^{* * * *}$
}

Received: 22.6. 2018

Preliminary communication

Accepted: 4. 3. 2019

UDC 37.07(497.5)

DOI https://doi.org/10.30924/mjcmi.24.si.4

\begin{abstract}
By combining the attributive-taxonomic and process approaches to the profession, resulting from different sociological traditions, the professional elements and the professionalization of school principals in Croatia are analysed. The research was conducted by survey method in 2017. The sample was convenient and included 73 principals who participated in the research activities of the Centre of Scientific Excellence for School Effectiveness and Management. Our results suggest that the job of school principals in Croatia cannot be considered a profession yet. There are no fundamental elements that differentiate the profession from an ordinary occupation. More specifically, there is a lack of expertise in the area of educational management and leadership (authority), cooperation with professional associations in defining the professional socialization (autonomy), as well as high social status
\end{abstract}

(attractiveness) as a result of the state of previous elements. Given the contextual specificity, the discussion presents incentives, obstacles and recommendations for further professionalization of school principals in Croatia. The importance of professional education is emphasized, whose design and implementation should involve representatives of principals' professional associations, as well as decentralization of education system so that theoretical expertise can be developed through the practice. As the trained practitioners focused on a benefit of the educational system stakeholders (altruism), the principals should set the conditions of the profession to make it more attractive for the best candidates.

Keywords: profession, professionalization, school principals, education, Croatia

\footnotetext{
${ }^{*}$ This research was supported by the Ministry of Science and Education of Republic of Croatia through Scientific of Excellence Centres and is a part of activities of Croatian Centre for School Effectiveness and Management re-search.

${ }^{* *}$ Renata Relja, PhD, University of Split, Faculty of Humanities and Social Sciences, Croatian Center of Scientific Excellence for School Effectiveness and Management, Department of Sociology, Poljička cesta 35, 21000 Split, E-mail: rrelja@ffst.hr

*** Toni Popović, University of Split, Faculty of Humanities and Social Sciences, Department of Sociology, Poljička cesta 35, 21000 Split, E-mail: tpopovic1@ffst.hr

***** Tea Gutović, University of Split, Faculty of Economics, Cvite Fiskovića 5, 21000 Split (adjunct assistant), E-mail: tgutovic@gmail.com
} 


\section{INTRODUCTION}

In a daily sense, doing something professionally means doing it well and knowingly, whether it is a paid work or not (Smerić, 2005; Reis Monteiro, 2015). On the other hand, the scientific approach to the profession is more specific and implies a certain way of organizing one's job. According to the International Labour Organization (ILO), the professions differ from other jobs by means of the skill level required to perform them. The expertise acquired through the specific university education is necessary. Science, education and schooling are some of the fields, among others, in which different professions are developed (e.g. health, ICT, business) (ILO, 2012; Reis Monteiro, 2015). Muzio et al. (2011) emphasize that profession is a job that is neither fully market-oriented nor conditioned by state decisions. It retains a certain autonomy, based on high competencies and serving the public good. As Šporer (1990) summarizes, the authority of expertise and the assumed altruism of professionals maintain a relative autonomy in defining professional standards.

The emergence of professions is a part of the wider process of democratization, greater division of labour and scientific and technological development. Their growth occurs in the $20^{\text {th }}$ century, especially after the Second World War, due to the growing public sector and the focus on service and knowledge economy (Santrić, 1990; Reis Monteiro, 2015). Many authors point to the importance of professions today. Giddens believes that we increasingly depend on decisions of experts and their knowledge (Zlatar, 2008). According to Beck (2001), professions are creative, reflexive and progressive intelligence that protects us in a society that is burdened with numerous risks. The scientific interest in professions is very obvious, particularly within management, sociology and organizational studies (Saks, 2012; Carvalho, 2017).

Over the past three decades, school principals have often been involved with the necessity of their professional development. Knowledge is a resource of today's world, but also a resource for the future. Schools should be successful in educating students, who will acquire the key competences and get ready to participate in lifelong learning. In this way, schools contribute to the socioeconomic development and to reducing the risk of social exclusion (Flecha, 2015).

A principal plays an important role as the cohesive element in realization of school potentials. Effective principal knows how to motivate teachers and other staff to develop and achieve school goals. Higher expectations of students, along with their positive assessment of school operations, lead to the more committed participation in school activities and higher academic achievements (Mulford, 2003; Popović et al., 2010).

In most countries of the world, principals cannot be considered a profession yet. Even if there is a formal and compulsory education, its quality is often questioned (e.g. most EU member states, the US). In some countries, an apprenticeship model is used, with future principals practising with mentors, and advancing in leadership positions in schools (Australia, Canada, African countries etc.). In others, they learn through the work experience after appointment (Popović et al., 2019). However, these models show insufficient preparation of candidates. Along with the growing complexity of educational management and leadership, and a widespread opinion on inappropriate principals' reputation, poor educational opportunities are the main reason for the globally reduced interest of teachers in a principal position (Stoll \& Temperley, 2009). 
The example of a country that puts importance in principals' professionalization is England. It went to the forefront in this process, developing professional standards, numerous education programs and principals' professional associations over the last thirty years. Education is decentralized to the extent that successful schools have considerable freedom in curricula, can hire staff according to their own criteria and teach others their practices. On the other hand, unsuccessful principals could be penalized, and their schools closed or restructured (Day \& Amstrong, 2016). However, there is no reduction in the candidate's interest in this job, and principals are very self-confident considering their obligations (Huber et al., 2008).

The school principals' professionalization in Croatia has begun since the beginning of this millennium. Education and licensure programs were designed in 2005 , but there was no political support in enabling their sustainability. At this moment, a new attempt is the ESF project School principal: profession and qualification, not function, which is headed by the University of Zadar. Within the project activities, the professional standards for principals, their qualifications and the postgraduate (specialist) study were developed (Vican et al., 2016). This project is a part of the broader efforts of the Croatian education system' modernization, introduced within the Strategy for Education, Science and Technology (2014). Another impulse was the introduction of the Croatian qualification framework, in line with the European standards, with the aim of harmonizing qualifications at the EU level. Nevertheless, the systematic professionalization of principals has been postponed in Croatia until 2021. The reasons are analysed in the discussion and implications of the paper.
In this paper, principals' professionalization is analysed by combining two sociological approaches to the profession. The first is attributive-taxonomic, which initially explores the existence of key elements that form the profession generally. In this respect, it is possible to argue about principals as occupation, semi-profession or profession (Santrić, 1990; Smerić, 2005). This approach has been established within the functionalist paradigm, attempting to explain what makes the professions socially prestigious (Reis Monteiro, 2015). The second is the process approach, originally created as a critique of functionalism. Its various forms (interactionist, neo-Weberian etc.) emphasize that the attributive-taxonomic approach represents an ideology of professionalism - the timeless idealized image of the profession (Carvalho, 2017). Issues such as misuse of power, corporate interests and conflicts as a result of professional closure are underlined, among others (Kuhlmann, 2013). This approach starts with the assumption that it is more important to explore what makes a profession in particular society than to follow pre-determined elements of professionalism. It provides considerable opportunities to analyse strategic orientations and power among the actors (Davies, 1996; Faulconbridge \& Muzio, 2011).

The combination of taxonomic and process analysis has been selected, according to a global consensus on what should be the essence of principals' profession (Nelson \& Slater, 2013; Clarke \& Wildy, 2013; Popović et al., 2019). In addition, these approaches are not necessarily in contradiction. By considering the elements of profession and process of principals' professionalization, the intention is to explore what has been achieved in the given social circumstances (Čulig 1999a; Smerić, 2005). 


\section{METHODOLOGY AND SAMPLING}

Our research was conducted in 2017. It is a part of the program of research activities organized by the Centre of Scientific Excellence for School Effectiveness and Management. The survey was used as the method, with the questionnaire developed to study the work of school principals. Only the responses related to their professionalization are analyzed in this paper. The sample is non-probabilistic - convenient. Nevertheless, previous research has shown that it reflects the trends in Croatian education well (Vican et al., 2016; Alfirević et al., 2018; Alfirević et al., 2018; Popović et al., 2019), which is a good starting point for the future research.

The sample has the following features (Table 1):

- the gender distribution is relatively similar (women - 50.7\%, men - 46.6\%);

- almost $90 \%$ of respondents have completed undergraduate or graduate studies, while others have obtained a science degree;

Table 1: Demographics of the sample

\begin{tabular}{|c|c|c|c|}
\hline & & \\
\hline & & f & $\%$ \\
\hline \multirow{3}{*}{ Gender } & Male & 34 & 46.6 \\
\hline & Female & 37 & 50.7 \\
\hline & $\mathrm{N} / \mathrm{A}$ & 2 & 2.7 \\
\hline \multirow{5}{*}{ Age } & $31-40$ & 5 & 6.8 \\
\hline & $41-50$ & 18 & 24.7 \\
\hline & $51-60$ & 37 & 50.7 \\
\hline & 61 or more & 11 & 15.1 \\
\hline & N/A & 2 & 2.7 \\
\hline \multirow{3}{*}{ Education } & Under/graduate study & 65 & 89 \\
\hline & Science degree & 7 & 9.6 \\
\hline & N/A & 1 & 1.4 \\
\hline \multirow{7}{*}{$\begin{array}{l}\text { Work experience at the principal's } \\
\text { position }\end{array}$} & $1-5$ & 27 & 37 \\
\hline & $6-10$ & 20 & 27.4 \\
\hline & $11-15$ & 9 & 12.3 \\
\hline & $16-20$ & 7 & 9.6 \\
\hline & $21-25$ & 5 & 6.8 \\
\hline & 26 or more & 1 & 1.4 \\
\hline & N/A & 4 & 5.5 \\
\hline \multirow{4}{*}{ County } & Varaždin & 30 & 41.1 \\
\hline & Split-Dalmatia & 23 & 31.6 \\
\hline & Dubrovnik-Neretva & 5 & 6.8 \\
\hline & $\mathrm{N} / \mathrm{A}$ & 15 & 20.5 \\
\hline \multirow{3}{*}{ Type of school } & Primary & 32 & 43.8 \\
\hline & Secondary & 39 & 53.5 \\
\hline & N/A & 2 & 2.7 \\
\hline \multirow{3}{*}{ School location } & Urban area & 41 & 56.2 \\
\hline & Rural area & 29 & 39.7 \\
\hline & $\mathrm{N} / \mathrm{A}$ & 3 & 4.1 \\
\hline
\end{tabular}


- $2 / 3$ of the sample is older than fifty $(65.8 \%)$, while the least represented are principals between 31 and 40 years of age $(6.8 \%)$, which may be related to the necessary work experience for that position and its long-term retention;

- most principals come from Varaždin and Split-Dalmatia County;

- principals from the primary $(43.8 \%)$ and secondary $(53.5 \%)$ schools are almost equally represented, while most of their schools are located in the urban areas $(56.2 \%)$.

The Strategy for Education, Science and Technology (2014), as well as the available research, suggest that school principals in Croatia cannot be considered a profession yet. Concerning the self-assessments of sample respondents, the hypotheses in this paper question the lack of professional elements:

$\mathrm{H}_{1}$. The additional knowledge on school management and leadership is needed.

$\mathrm{H}_{2}$. The principals do not cooperate enough with their professional associations, regardless of the sample characteristics.

$\mathrm{H}_{3}$. The job of a principal is not highly appreciated in the society, regardless of the sample characteristics.

$\mathrm{H}_{4}$. The principals are mostly satisfied with their job and intend to become principals in an additional term.

\subsection{Limitations}

The paper has the following limitations. First, the questionnaire emerged within the wider interests of the Centre of Scientific Excellence for School Effectiveness and Management. They concern the work of school boards, teachers and principals in primary and secondary schools. The aim is to identify key challenges faced by schools and their principals, as well as to offer scientifically based recommendations for improving the organizational performance. Within the questionnaire addressed to principals, various aspects of their work and elements of school atmosphere are considered. When it comes to the professional elements, more attention is given only to expertise, i.e. the existing and required levels of knowledge in school management and leadership. Such an interest is not surprising, since the expertise is the basis of every profession and successful solving of complex tasks. Numerous authors have investigated the educational needs of Croatian principals in recent years (e.g. Rogić \& Karamatić Brčić, 2016; Vican, 2016; Radeka, 2016; Popović et al., 2019). In our research instrument, other professional elements (cooperation with professional associations, principals' social status) are explored only partially.

The second limitation stems from the characteristics and type of the sample. Alfirević et al. (2011) consider convenient samples of motivated school principals, attending various types of professional education and development, as a sample relevant for education policy development. Nevertheless, a non-probabilistic sample of principals from predominantly two counties limits the possibilities for generalization of our findings. The results are certainly indicative, given the available research and barriers to principals' professionalization.

Finally, a limitation may be found in the specific social context, found in Croatia and the region. It is determined by the inconsistency of centralized education system and the labour market (Matković, 2011, Obadić, 2017). Principals mostly carry out decisions of the centralized education policy, which delays the necessity of their systematic 
professionalization (Popović et al., 2019). Although the importance of contextualsensitive approach to research on professions has been emphasized in recent years, the importance of comparative studies that will inform theories and concepts has been emphasized also (Adams, 2014). In this regard, the results and implications of our study are applicable primarily in the postsocialist countries of South East Europe (SEE), while their utilization in other social contexts is limited.

\section{RESULTS: PRINCIPALS' ATTITUDES ON ELEMENTS OF THEIR OCCUPATION}

Continuous data collection on school principals' work is important in order to observe the potential changes that differentiate the profession from an ordinary occupation or semi-profession. Changes need to be interpreted by taking into account the wider social context. These are preconditions for successful directing of the school principals' professionalization, which is promoted as the strategic goal of education system in Croatia. In this part of the paper, our intention is to interpret principals' responses on the elements of profession when considering their job. Through the discussion and implications, the incentives, obstacles and recommendations for the further school principals' professionalization in Croatia are explained in more detail. By combining the attributive-taxonomic and the process approach, a development direction of particular occupation can be recognized (Šporer, 1990; Smerić, 2005). In other words, we examine the articulation level of elements that are needed to form the principals' profession in the SEE social context.

For the professionalization of school principals or any other occupation, a necessity of systematic and extensive education, i.e. the expertise, is highlighted. The professional reputation depends on expertise. Without it, a demand for exclusive professional competence, relative work autonomy and high privileges is not founded (Abbot, 1991; Čulig, 1999a). In the comparative analysis of principals' professionalization in the international context, Popović et al. (2019) highlight university education as the condition sine qua non of the profession. In the initial phase of this process in Croatia, there is a greater interest in principals' education than in the other elements that constitute the profession. The project School principal: profession and qualification, not function is focused precisely on the knowledge, skills and competencies that principals should possess (Vican, 2016). Their systematic transmission, foreseen for the future, is based on the establishment of professional standards, qualifications and postgraduate studies.

According to Table 2, the need for school principals' professional development in Croatia is clearly noticeable. Respondents point out that they have a certain level of expertise in each of the professional fields (ranging from $\mathrm{M}=2.73$ to $\mathrm{M}=4.31$ ). Interestingly, respondents emphasize the relatively high importance of many proposed fields of expertise $(\mathrm{M}=3.5$ or higher), especially for school entrepreneurship, benchmarking, marketing, and strategic (development) and financial planning for the school improvement.

Expertise in many areas of school management and leadership, some of which are relatively new, can be explained by the studies, which show that principals in Croatia occasionally attend various forms of non-formal education - workshops, seminars, conferences, consulting services etc. (Eurydice, 2013). Such programs cannot substitute the formal education. They are often criticized for ad hoc character, 
Table 2: Self-assessment of existing and required principals' expertise

\begin{tabular}{|l|c|c|c|c|}
\cline { 2 - 5 } \multicolumn{1}{c|}{} & \multicolumn{2}{l}{ Existing knowledge } & \multicolumn{2}{l|}{ Knowledge needed } \\
\cline { 2 - 5 } \multicolumn{1}{c|}{} & $\mathbf{M}$ & $\mathbf{S D}$ & $\mathbf{M}$ & $\mathbf{S D}$ \\
\hline Strategic (development) planning & 3.42 & 0.921 & $\mathbf{3 . 8 5}$ & 0.938 \\
\hline Annual planning and programming of school activities & 4.31 & 0.664 & 3.18 & 1.079 \\
\hline School management & 3.63 & 0.717 & $\mathbf{3 . 7 9}$ & 0.887 \\
\hline Teamwork, motivation and leadership & 3.75 & 0.741 & $\mathbf{3 . 8 3}$ & 0.934 \\
\hline Communication with school staff & 3.95 & 0.743 & 3.46 & 1.02 \\
\hline Work and process organization at school & 4.14 & 0.732 & 3.39 & 1.015 \\
\hline Management of time, meetings and delegation of tasks & 3.85 & 0.908 & 3.33 & 0.919 \\
\hline School monitoring and evaluation & 3.68 & 0.65 & $\mathbf{3 . 7 1}$ & 0.846 \\
\hline School marketing & 3.14 & 0.933 & $\mathbf{3 . 8 9}$ & 0.832 \\
\hline Public and media relations & 3.3 & 0.908 & $\mathbf{3 . 6 9}$ & 0.919 \\
\hline Financial planning and control & 3.47 & 0.987 & $\mathbf{3 . 8 5}$ & 0.980 \\
\hline Accounting (knowledge needed for cooperation with & 3.21 & 1.027 & $\mathbf{3 . 7 4}$ & 1.021 \\
\hline accountants) & 3.58 & 0.865 & $\mathbf{3 . 7 9}$ & 0.992 \\
\hline Management of projects and special events (manifestations) & 3.45 & 0.867 & $\mathbf{3 . 7 6}$ & 1.028 \\
\hline Fundraising & 2.73 & 1.193 & $\mathbf{3 . 6 6}$ & 1.146 \\
\hline Outsourcing management & 3.63 & 0.950 & $\mathbf{3 . 8 3}$ & 0.979 \\
\hline School legislation & 3.55 & 0.929 & $\mathbf{3 . 7 6}$ & 0.880 \\
\hline Inclusion of children with special needs & 3.33 & 0.834 & $\mathbf{3 . 9}$ & 0.772 \\
\hline Benchmarking & 3.49 & 0.852 & $\mathbf{3 . 9}$ & 0.952 \\
\hline Entrepreneurial behaviour of schools and principals & 3.78 & 0.901 & $\mathbf{3 . 8 7}$ & 0.893 \\
\hline Crisis management & & & & \\
\hline
\end{tabular}

Note: Measured on the standard, five-point Likert scale.

superficiality, incoherence and biases arising from the specific perspective adopted by the organisers (ministries, trade unions, agencies, consulting firms etc.) (Scott \& Scott, 2013). Non-formal education, however, makes it easier for school principals to carry out their daily activities, which is important due to the growing expectations of stakeholders.

Our research supports such findings. The principals need additional expertise, which confirms the first research hypothesis $\left(\mathrm{H}_{1}\right)$. The launch of postgraduate (specialist) studies for the education of school principals, established at the University of
Zadar and the Faculty of Humanities and Social Sciences in Rijeka, is an important step in their professionalization. Whether these programs will succeed depends on the systematisation of this process, in particular, on the legal obligations. So far, formal education for school principals depends on the intrinsic motivation of the potential students. In the conditions of insufficient school funding and numerous administrative obligations of the principals, this is not a good basis for the sustainability of the principal profession (Staničić, 2006).

Another distinctive element of professions is autonomy, i.e. the self-regulation 


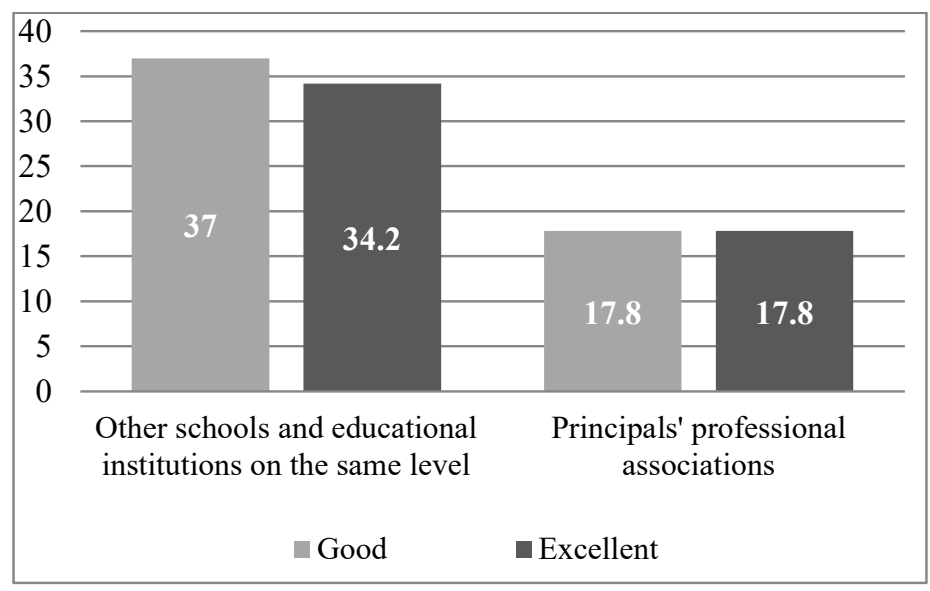

Figure 1: Cooperation of school principals with institutions in the education system (\%)

resulting from the authority of knowledge and the altruistic orientation of professionals. It is based on the assumption that a fellow professional is most credible in judging professional work (Smerić, 2005). In order to achieve autonomy in the sense of professional socialization and culture, it is necessary to be a member of the professional associations that will strengthen the expertise and legalize it as the way of performing tasks (Santrić, 1990; Čulig, 1999b). Any profession that insists on a high level of development has a professional association that determines the conditions of its autonomy with other actors, such as state, clients, universities and supranational organizations (regulatory and professional) (Faulconbridge \& Muzio, 2011).

There are two professional associations of primary and secondary school principals in Croatia. In this paper, their activity has not been analyzed. However, we asked respondents to evaluate cooperation with them. Good cooperation is necessary to legitimize these associations as the carriers of principals' professional development. Unfortunately, it is absent, if judged by the answers. Only one third of respondents consider cooperation to be good or excellent, while the assessment is significantly better in the case of schools and other educational institutions on the same level (Figure 1).

Respondents mostly agree on this issue, which is confirmed by the results of the Chi-Square test. The statistically significant differences are present only for the fact that primary school principals evaluate the cooperation with professional associations somewhat low (Table 2). Our results suggest that the second research hypothesis is mostly confirmed $\left(\mathrm{H}_{2}\right)$. The cooperation of principals with their professional associations is insufficient, which confirms that these associations do not have a significant role in defining the professional standards and qualifications for school principals.

Based on the expertise, autonomy and altruistic orientation, professions achieve a high social status. As the neo-Weberian and conflict perspectives point out, the reputation of professions often drops, due to variety of affairs, reduction of the information gap between experts and the public, dissemination of alternative practices etc. (Groenwegen, 2006; Reis Monteiro, 2014). According to Adams (2014), the loss of trust is one of the most frequently 
Table 2: Relationship between sample characteristics and attitudes on cooperation with professional associations

\begin{tabular}{|l|c|c|c|}
\cline { 2 - 4 } \multicolumn{1}{c|}{} & $x^{2}$ & df & p \\
\hline Gender & 6.344 & 4 & 0.175 \\
\hline Age & 15.241 & 12 & 0.229 \\
\hline Work experience at principal's position & 4.659 & 8 & 0.793 \\
\hline County & 4.088 & 8 & 0.849 \\
\hline Type of school & $\mathbf{9 . 8 6 8}$ & $\mathbf{4}$ & $\mathbf{0 . 0 4 3}$ \\
\hline School location & 0.848 & 4 & 0.932 \\
\hline
\end{tabular}

investigated topics in the field of the sociology of professions since 1990s. Although we did not analyse the altruistic orientation of principals and professional ethics in its background, we assumed that the principals' social status in Croatia is not high. Extensive reporting on the results of Croatian students in PISA tests, failure to implement the curricular reform, and incoherence of education with the needs of the labor market are some of the reasons why the public is sceptic, considering the efficiency of schools. According to the results, the principals feel that their work is not particularly appreciated in society $(42.5 \%)$. Only one fifth considers the opposite, while another fifth has mixed views on this issue, i.e. they do not agree nor disagree (Figure 2).
Results are far more favourable when assessing the principals' social status in a local community. Most of respondents (56.1\%) consider it to be high (Figure 2). This can be interpreted by the greater influence that principals carry out in their community and by the more favourable opinion of respondents' own work in relation to principals in general. Despite this consideration, the disparity in responses on the social status of principals re-emphasizes the need for decentralization of education system. It should be followed by raising the competences of principals and other school staff. These are necessary preconditions for the efficient schools and a higher social status of their principals.

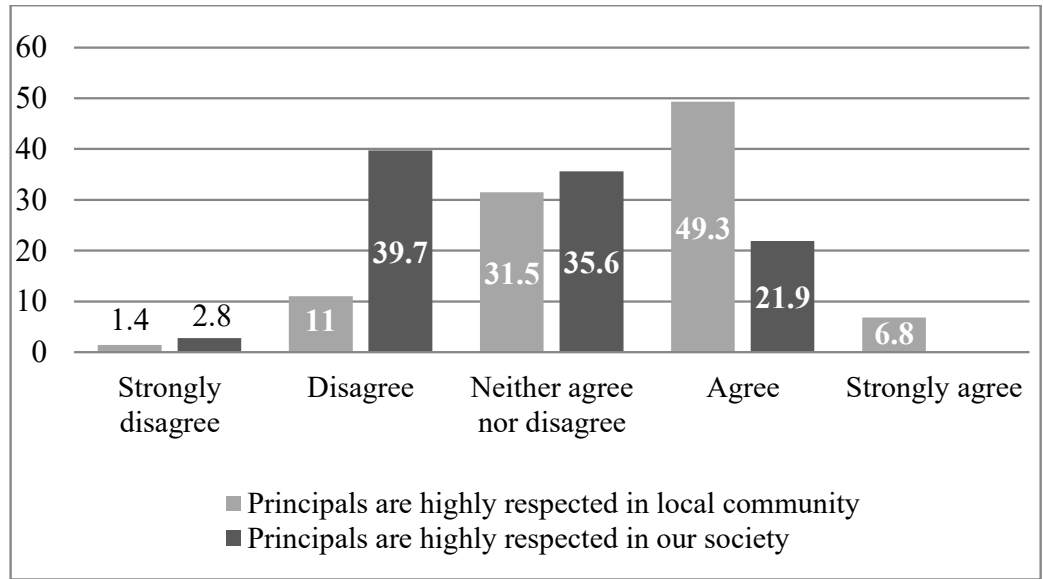

Figure 2: Principals'social status (\%) 
Journal of Contemporary Management Issues

Table 3: Relationship between sample characteristics and attitudes on principals'social status

\begin{tabular}{|c|c|c|c|c|}
\cline { 2 - 5 } \multicolumn{1}{c|}{} & & $\chi^{\mathbf{2}}$ & $\mathbf{d f}$ & \multicolumn{1}{c|}{$\mathbf{p}$} \\
\hline \multirow{4}{*}{$\begin{array}{c}\text { Social status at } \\
\text { local community } \\
\text { level }\end{array}$} & Gender & 6.472 & 4 & 0.167 \\
\cline { 2 - 5 } & Age & 9.094 & 12 & 0.695 \\
\cline { 2 - 5 } & Work experience at principal's position & 11.859 & 8 & 0.158 \\
\cline { 2 - 5 } & County & 5.352 & 8 & 0.719 \\
\cline { 2 - 5 } & Type of school & 3.087 & 4 & 0.543 \\
\hline \multirow{4}{*}{$\begin{array}{c}\text { Social status at } \\
\text { societal level }\end{array}$} & School location & $\mathbf{1 . 8 0 6}$ & $\mathbf{4}$ & $\mathbf{0 . 0 4 1}$ \\
\cline { 2 - 5 } & Gender & 3.158 & 3 & 0.368 \\
\cline { 2 - 5 } & Age & 3.337 & 9 & 0.947 \\
\cline { 2 - 5 } & Tork experience at principal's position & 5.331 & 6 & 0.502 \\
\cline { 2 - 5 } & County & 4.211 & 6 & 0.648 \\
\cline { 2 - 5 } & Type of school & 1.061 & 3 & 0.786 \\
\hline
\end{tabular}

The statistically significant differences were not found using the Chi-Square test in estimating the principals' social status at the societal level (Table 3). The only difference is the level of local community. School principals in rural areas tend to estimate their status somewhat more favourable. Such results suggest the acceptance of the third hypothesis $\left(\mathrm{H}_{3}\right)$. Regardless of the sample characteristics, principals consider their work not to be highly appreciated in our society.
Despite the disadvantages of the Croatian education system, the satisfaction of school principals with their job is hypothesized. The attitudes on social status of principals in a local community are related to such presumption. In addition, most respondents $(60.1 \%)$ believe they are doing the best they can in the given circumstances, i.e. they don't believe that the improvement of their work can significantly change the school outcomes. While some studies consider principals' satisfaction as a

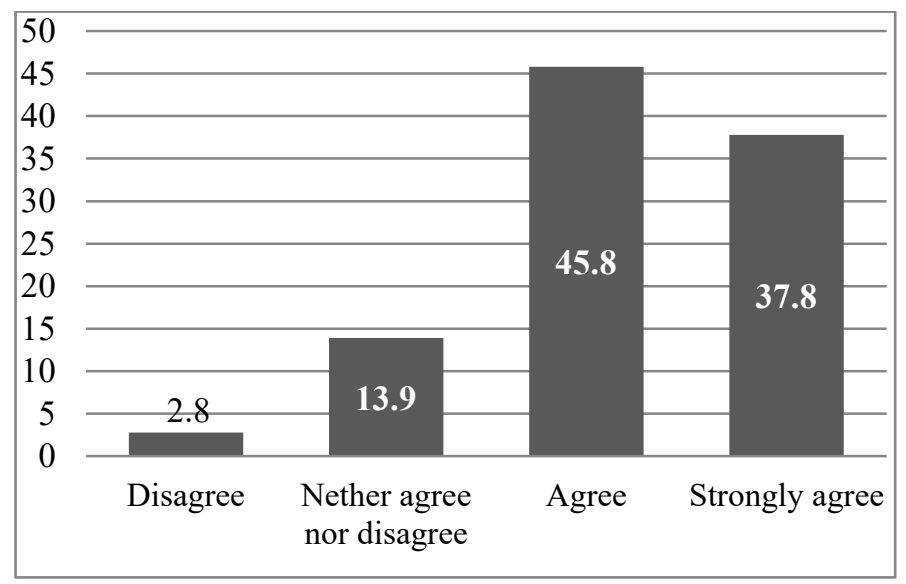

Figure 3: Job satisfaction (\%) 
predictor of successful school performance (Ivanov, 2016), it can also contribute to maintaining the status quo regarding their professionalization. Results on the cooperation with professional associations and the occasional use of non-formal education support this assumption, which should be further examined.

Principals are very satisfied with their job in a professional sense - only $2.8 \%$ points out the opposite (Figure 3). Furthermore, most respondents $(75.3 \%)$ intend to become principals in an additional term, while only $15.1 \%$ don't intend to do so. Half of them indicate the retirement as the reason, which is consistent with the dominant age group of respondents. Others emphasize "a great deal of administrative tasks", "poor cooperation with parents," "poor principals' status," "lack of support from the institutions", "lack of principals' autonomy", "insufficient rewards for successful principals and schools", "insufficient payments considering the obligations" etc. Nonetheless, the results confirm the fourth research hypothesis that principals are mostly satisfied with their job and intend to become principals in an additional term $\left(\mathrm{H}_{4}\right)$.

\section{DISCUSSION AND IMPLICATIONS: INCENTIVES, OBSTACLES AND SUGGESTIONS FOR PRINCIPALS' PROFESSIONALIZATION IN CROATIA}

Analysis of the professional elements shows that school principals in Croatia cannot be considered as profession yet. Within the continuum between occupation and profession, they are located somewhere in-between and could be described as the 'semi-profession' (Šporer, 1990; Smerić, 2005). In Croatia, as in the other European countries, work experience in the education system and teaching qualifications are required for this job (Eurydice, 2013). Some professional elements gain momentum in Croatia, such as refining of the professional standards and qualifications, including the development of postgraduate studies. More attention should be paid to other elements of professionalization, such as cooperation between principals' professional organizations and improving of their performance. With the synergy of these elements, while complying with the clear professional ethics (both within and outside the legal provisions) (Smerić, 2005), it is realistic that legal autonomy of the professional work should be formally established. Otherwise, principals will remain at a relatively similar level of professional development, while others will make the important decisions on their issues (Čulig, 1999a). Understanding of principals as the 'semi-profession' is primarily an indication, i.e. a preliminary insight, requiring systematic research into the further process of professionalization. Some of the potential research topics are mentioned in the next chapter.

When it comes to the incentives, obstacles and further suggestions for the professionalization of principals, discussion and implications can be analyzed on the three levels (Santrić, 1990). Ambivalent factors operate on each of them, so the pace and path of this process for the future is not clear at this moment.

(1) On the macro level, it is certainly encouraging that principals' professionalization has become an important issue almost everywhere in the world. Schools foster the mediocrity if there is no permanent development of their staff and the promotion of learning (Burton et al., 2011). Knowledge 
has become perhaps the most important capital of modern times. In this regard, the European Union seeks to strengthen the common labour market based on clear and comparable qualifications, insisting on their quality. Attention is, therefore, paid to the modernization of education systems and professional development of school staff.

The principals' professional development is hindered in Croatia by insufficient articulation of the role of education within the socio-economic development, which is currently missing. Hence the education is changing very slowly. Consequences are the peripheral position of the service society in Croatia, with regard to the international level, and a low participation in adult education (Peračković, 2010; Brčić Kuljiš \& Koludrović, 2016). In such social conditions, the centralization of education system can last for a long time and have negative impacts on development of professional elements of school principals.

(2) Mezzo level includes education as a social subsystem. Macro level impacts are clearly reflected here by the fact that the implementation of the Strategy for Education, Science and Technology, adopted in 2014, is still inadequate. The trademarks of the proposed educational reform are conflicts of different groups within the subsystem. No profession is completely homogeneous, so occasional tensions may exist among its stakeholders (practitioners, experts in managerial positions, academic staff that provides knowledge etc.) (Andrews \& Wærness, 2011). However, conflicts in Croatian education system seem to be a perpetual feature, because of the absence of social reforms in general. Such reforms would enable socio-economic development with a clear role of education. Otherwise, there is much room for symbolic and ideological conflicts. While conflicts may well be used to legitimize the importance of education, they are undoubtedly an additional burden for the implementation of reforms in this subsystem.

Further development of education programs can be done at the mezzo level, thus strengthening the school principals' professionalization. The non-formal education is often criticized for lack of systematisation, while formal education overlooks practice due to the focus on theories. International studies suggest their simultaneous development that will continually provide knowledge for the successful appointment and retention of the principal position (Darling Hammond et al., 2010). Mentoring is also proposed as a part of the formal programs and a form of linking theory with practice. Mentors prepare candidates for practice and allow them to access professional networks (Mulford, 2003). In line with such recommendations, the postgraduate study for education of school principals, conducted by the Faculty of Humanities and Social Sciences in Rijeka, has introduced the work with prominent mentors in schools. Mentoring can be a mode of connecting universities and principals' professional associations. Universities need to empower such associations through the joint conferences, research projects, reform initiatives etc. Well-organized professions are much more successful in expanding the expertise and legitimizing their competences.

(3) Micro level refers to the school context. When the macro- and mezzo- level conditions become more favourable, we should not expect the educational decentralization and professional development of school staff to develop without resistance. According to the research in the postsocialist countries of Southeast Europe, teachers are not interested in participating in school leadership and activities that are 
not determined by an employment contract (Terek et al., 2015; Nathanailli, 2015; Vican et al., 2016). Such passivity stems from an over-reliance on hierarchical structure and the pure implementation of ascribed tasks, which is the legacy of education in socialists' economies, where flexible workers were not needed. Surely, it will not be easy to become a professional principal in such an environment, especially if other employees do not share the work enthusiasm. On the other hand, some studies show that even a part of principals do not communicate enough their decisions with other employees (Blažević, 2014). These are noticeable deficits for the development of participative leadership on which modern education institutions are based (Vican et al., 2016).

The educational authorities are not particularly persistent in the professionalization of school principals. Entrepreneurial behaviour is a recommendation for the future. In addition to solving the current problems, it can create the strategic perspectives of the school. Principals should be encouraged to develop the educational management and leadership skills among the school staff, for this is a prerequisite of quality work and school effectiveness.

\section{CONCLUSION}

Acceptance of the first research hypothesis in this paper was expected, due to the strategic efforts that point to the necessity of school principals' professional development in Croatia. Lack of principals' professional expertise is the recent topic of education policy even globally. It is hard to expect a relevant social status of principals whose students do not gain high educational achievements. They are expected to be determined, competent and creative in running the school. On the group level, through the principals' professional associations, the impact on the design of a favourable education policy is expected, as well. Unfortunately, significantly improved results of Croatian students on international tests are still missing, as is the modernization of the education system in general. Responsibility for such a situation can be attributed to different stakeholders of this social subsystem, as highlighted in the previous chapter.

The insufficient co-operation of principals within their professional associations has been also hypothesized in the second hypothesis. At this moment, it does not seem that principals are a strong and cohesive group that significantly affects educational policies. Consequently, their relatively low status at the societal level is reasonable, which proved the third hypothesis. Most principals, however, intend to keep their job in the future, which can be linked to their high professional satisfaction (fourth hypothesis). In their opinion, they are doing the best they can in the current situation of centralized education that limits individual initiatives and development of schools that would meet the needs of the labour market and the imperatives of lifelong learning. The decentralized education policy is needed, along with the professional development of school staff, in order to effectively deal with ever greater responsibilities. Principals' active engagement and cohesion are needed for the improvement of the schools and education system as a whole. Otherwise, achieving its strategic goals seems hopeless. The efficiency of their professionalization needs to be more systematically explored in the future in order to guide these processes scientifically, with the ultimate intent of improving school results.

An important research topic is the satisfaction of attendants of postgraduate 
studies. Of great importance for the principals' professionalization may be the analysis of usability of the acquired knowledge in such a way. This can be done, for example, by conducting a comparative analysis of differences in the work of principals who attended study programs and those who did not. Differences in entrepreneurial values and practices, orientation towards stakeholders and self-efficacy are some of the possible research topics. The professional programs should be tailored in line with the findings. In spite of several papers that question principals' orientation towards the education stakeholders (e.g. Alfirević et al., 2011; Pavičić et al., 2016), systematic and occasional research on altruism of school principals is necessary. In

\section{References}

1. Abbot, A. (1991). The Order of Professionalization. Work \& Occupations, 18(4): 355-384.

2. Adams, T. L. (2014). Sociology of professions: international divergences and research directions. Work, Employment \& Society, 29(1): 154-165.

3. Alfirević, N., Pavičić, J., Mihanović, Z., \& Relja, R. (2011). StakeholderOriented Principal Development in Croatian Elementary Schools. Revija za socijalnu politiku, 18(1): 47-60.

4. Alfirević, N., Pavičić, J., \& Najev Čaćija, Lj. (2018). Inicijalna empirijska verifikacija modela interne marketinške orijentacije za vrednovanje i unapređenje rada školskih odbora u Republici Hrvatskoj. Ekonomski pregled, 69(5): 475-511.

5. Alfirević, N., Vican, D., Pavičić, J., \& Petković, S. (2018). Entrepreneurial Orientation of School Principals and Principalship in Croatia and Bosnia such an orientation, the meaning of profession that serves the public good is achieved, balancing between different aspirations of the market and bureaucratic organizations (Freidson, 2011, Riska, 2010).

Qualitative methods should also be applied more frequently. They are designed to reach smaller populations, such as professional teams and associations, as well as topics, such as participation in decisionmaking, together with relevant ministries and agencies, the effectiveness of legislation etc. Overall, the recentness of school principals' professionalization is noteworthy, which opens up numerous opportunities for conducting research in future.

\& Herzegovina: Psychological, Educational and Social Perspectives. Revija za socijalnu politiku, 25(1): 85-96.

6. Andrews, T. M., \& Wærness, K. (2011). Deprofessionalization of a female occupation: Challenges for the sociology of professions. Current Sociology, 59(1): 42-58.

7. Beck, U. (2001). Pronalaženje političkoga - prilog teoriji refleksivne modernizacije. Zagreb: Naklada Jesenski i Turk.

8. Blažević, I. (2014). Principal's Leading Role in the School. Školski vjesnik, 63(1-2): 7-21.

9. Brčić Kuljiš, M., \& Koludrović, M. (Eds.) (2016). Stanje $i$ perspektive obrazovanja odraslih. Split: Faculty of Humanities and Social Sciences.

10. Burton, L., Krug Carper, M., \& Wilburn, V. (2011). The Sociology of Educational Supervision. Journal of Cross-Disciplinary Perspectives in Education, 4(1): 24-33. 
11. Carvalho, T. (2017). The Study of the Academic Profession - Contributions from and to the Sociology of Professions. Theory and Method in Higher Education Research, 3: 59-76.

12. Clarke, S., \& Wildy, H. (2013). Investing Preparation for the Principalship: Deliberating on Possibilities. In C. L. Slater \& W. S. Nelson (Eds.), Understanding the Principalship: An International Guide to Principal Preparation (pp. 25-43). Bingley: Emerald Group Publishing Limited.

13. Čulig, B. (1999a). Sociologija kao studij i struka. Empirijska analiza jedne populacije. Revija za sociologiju, 30(12): $19-43$.

14. Čulig, B. (1999b). Profesijska edukacija: procjene i aspiracije. Revija za sociologiju, 30(3-4): 211-227.

15. Darling-Hammond, L., Meyerson, L., LaPointe, M., \& Orr, M. (2010). Preparing Principals for a Changing World: Lessons from Effective School Leadership Programs. San Francisco: Jossey-Bass.

16. Davies, C. (1996). The Sociology of Professions and the Profession of Gender. Sociology, 30(4): 661-678.

17. Day, C., \& Amstrong, P. (2016). England: School Leadership Research in England. In A. Ärlestig, C. Day \& O. Johannson (Eds.), A Decade of Research on School Principals (pp. 245-268). Cham, Heidelberg, New York, Dordrecht, London: Springer.

18. Eurydice (2013). Ključni podaci o nastavnicima $i$ ravnateljima škola $u$ Europi. Izdanje 2013. Izvješće Eurydicea. Luxembourg: The Publication Office of the European Union.

19. Faulconbridge, J. R., \& Muzio, D. (2011). Professions in a globalizing world: Towards a transnational sociology of the Professions. International Sociology, 27(1): 136-152.

20. Flecha, R. (Ed.) (2015). Successful Educational Actions for Inclusion and Social Cohesion in Europe. Cham, Heidelberg, New York, Dordrecht, London: Springer.

21. Freidson, E. L. (2001) Professionalism: The Third Logic. Chicago: University of Chicago Press.

22. Groenewegen, P. (2006). Trust and the sociology of the professions. European Journal of Public Health, 16(1): 3-6.

23. Huber, S., Moorman, H., \& Pont, B. (2008). The English approach to system leadership. In B. Pont, D. Nusche \& D. Hopkins (Eds.), Improving School Leadership. Volume 2: Case Studies on System Leadership (pp. 111-152). Paris: OECD.

24. International Labour Office (2012). International Standard Classification of Occupations. Geneva: ILO.

25. Ivanov, L. (2016). Samoefikasnost i njezina važnost $\mathrm{u}$ ravnateljskom poslu. In D. Vican, I. Sorić, \& I. Radeka (Eds.), Kompetencijski profil ravnatelja: upravljanje odgojno-obrazovnom ustanovom (pp. 233-256). Zadar: University of Zadar.

26. Kuhlmann, E. (2013). Sociology of Professions: Towards International Context-Sensitive Approaches. South Africa Review of Sociology, 44(2): 7-17.

27. Matković, T. (2011). Obrasci tranzicije iz obrazovnog sustava $u$ svijet rada $u$ Hrvatskoj. PhD dissertation.. Zagreb: Pravni fakultet u Zagrebu.

28. Mulford, B. (2003). School Leaders. Changing Roles and Impact on Teacher and School Effectiveness. Bruxelles: Organization for Economic Cooperation and Development. 
29. Muzio, D., Kirkpatrick, \& I., Kipping, M. (2011). Professions, organizations and the state: Applying the sociology of the professions to the case of management consultancy. Current Sociology, 59(6): 805-824.

30. Nathanailli, V. (2015). School leadership in pre-university Albanian education system (1995-2012): Politics, issues and trends. Journal of Educational and Social Research, 5(3): 201-208.

31. Nelson, W. S., \& Slater, C. L. (2013). Lessons in Leadership from the Vineyard. In C. L. Slater \& W. S. Nelson (Eds.), Understanding the Principalship: An International Guide to Principal Preparation (pp. 3-21). Bingley: Emerald Group Publishing Limited.

32. Obadić, A. (2017). Nezaposlenost mladih i usklađenost obrazovnog sustava s potrebama tržišta rada. Ekonomska misao i praksa, 26(1): 121-150.

33. Pavičić, J., Alfirević, N., Vlašić, G., Krupka, Z., \& Krce Miočić, B. (2016). School Principals, Environments and Stakeholders: The Blessings and Heresies of Market Organization, In N. Alfirević, J. Burušić, J. Pavičić, R. Relja (Eds.), School Effectiveness and Educational Management - Towards a South-Eastern Europe Research and Public Policy Agenda (pp. 27-48). London: Palgrave Macmillan.

34. Peračković, K. (2010). (Za)što raditi u postindustrijskom društvu? Zagreb: Alinea.

35. Popović T., Alfirević N., \& Relja R. (2019). Selection and Education of School Principals: A Comparative Overview of Policies. In A. Ingpórsson, N. Alfirević, J. Pavičić, D. Vican (Eds.), Educational Leadership in Policy: Challenges and Implementation
Within Europe (pp. 59-78). Cham: Palgrave Macmillan.

36. Radeka, I. (2016). Kontinuirani profesionalni razvoj u odgojno-obrazovnoj ustanovi. In D. Vican, I. Sorić, \& I. Radeka (Eds.), Kompetencijski profil ravnatelja: upravljanje odgojno-obrazovnom ustanovom (pp. 53-77). Zadar: University of Zadar.

37. Reis Monteiro, A. (2015). The Teaching Profession: Present and Future. Cham, Heidelberg, New York, Dordrecht, London: Springer.

38. Riska, E. (2010). Health Professions and Occupations. In W. C. Cockerham (Ed.), The New Blackwell Companion to Medical Sociology (pp. 337 354). Malden, Oxford, \& Chichester: Blackwell Publishing Ltd.

39. Rogić, A. M., \& Karamatić Brčić, M. (2016). Cjeloživotno učenje ravnatelja. In D. Vican, I. Sorić, \& I. Radeka (Eds.), Kompetencijski profil ravnatelja: upravljanje odgojno-obrazovnom ustanovom (pp. 79-86). Zadar: University of Zadar.

40. Saks, M. (2012). Defining a profession: The role of knowledge and expertise. Professions and Professionalism, 2(1), 1-10.

41. Santrić, V. (1990). Osnovni tokovi i problemi profesionalizacije zanimanja: slučaj sestrinstva. Revija za sociologiju, 21(2): 311-339.

42. Scott, S., \& Scott D. E. (2013). Principal Preparation Experiences. In C. L. Slater, \& W. S. Nelson (Eds.), Understanding the Principalship: An International Guide to Principal Preparation (pp. 45-70). Bingley: Emerald Group Publishing Limited.

43. Smerić, T. (2005). Sparta ured Babilona: sociologijski aspekti vojne profesije. Zagreb: Hrvatska sveučilišna naklada. 
44. Staničić, S. (2006). Human Resources Management in the School System. Odgojne znanosti, 18(2): 515-533.

45. Stoll, L., \& Temperley, J. (2009). Improving School Leadership: The Toolkit. Paris: Organisation for Economic Co-operation and Development.

46. Strategy for Education, Science and Technology (2014). Narodne novine 124/2014.

47. Šporer, Ž. (1990). Sociologija profesija. Ogled o društvenoj uvjetovanosti profesionalizacije. Zagreb: Croatian Sociological Association.

48. Terek, E., Nikolic, M., Gligorović, B., Glušac, D., \& Tasić, I. (2015). The impact of leadership on the communication satisfaction of primary school teachers in Serbia. Educational Sciences: Theory and Practice, 15(1): 73-84.

49. Vican, D. (2016). Čimbenici koji otežavaju ravnateljski posao u kontekstu centralizacije i decentralizacije odgojno-obrazovnog sustava: prilog profesionalizaciji ravnateljskog zanimanja. In D. Vican, I. Sorić, \& I. Radeka (Eds.), Kompetencijski profil ravnatelja: upravljanje odgojno-obrazovnom ustanovom (pp. 25-51). Zadar: University of Zadar.

50. Vican, D., Relja, R., \& Popović, T. (2016). Principals Educational Leadership. In N. Alfirević, J. Burušić, J. Pavičić, R. Relja (Eds.), School Effectiveness and Educational Management - Towards a SouthEastern Europe Research and Public Policy Agenda (pp. 87-106). London: Palgrave Macmillan.

51. Zlatar, J. (2008). Anthony Giddens: Refleksivna projekcija osobnosti. Revija za sociologiju, 39(3): 161-182. 


\section{ANALIZA ELEMENATA I PROCESA PROFESIONALIZACIJE RAVNATELJA ŠKOLA U HRVATSKOJ}

\begin{abstract}
Sažetak
Kombiniranjem atributivno-taksonomskog $i$ procesnog pristupa profesiji, proizašlih unutar različitih socioloških tradicija, analiziraju se elementi profesije $i$ profesionalizacija ravnatelja škola u Hrvatskoj. Istraživanje je provedeno metodom ankete tijekom 2017. godine. Uzorak je prigodan, a obuhvatio je 73 ravnatelja koji su sudjelovali u programu istraživačkih aktivnosti Znanstvenog centra izvrsnosti za školsku efektivnost $i$ menadžment. Dovodeći ih u vezu s prethodnim istraživanjima Centra, naši rezultati pokazuju kako ravnatelje u Hrvatskoj ne možemo smatrati profesijom, jer izostaju temeljni elementi koji razlikuju zanimanje od profesije. Specifičnije, nedostaju ekspertiza u području obrazovnog upravljanja i vođenja (autoritet),
\end{abstract}

suradnja sa strukovnim udrugama $u$ definiranju profesionalne socijalizacije (autonomija) $i$ visoki socijalni status (atraktivnost) kao posljedica prethodnih elemenata. Ukazujući na kontekstualne specifičnosti, u diskusiji se iznose poticaji, prepreke i preporuke za daljnju profesionalizaciju ravnatelja. Ističe se važnost profesionalnog obrazovanja u čijem osmišljavanju i provedbi trebaju sudjelovati predstavnici strukovnih udruženja ravnatelja, kao i decentralizacija školstva kako bi se ekspertiza mogla razvijati u praksi. Kao profesionalci usmjereni na dobrobit dionika sustava obrazovanja (altruizam), ravnatelji trebaju odredivati uvjete profesije zbog njene atraktivnosti $i$ privlačenja najboljih kandidata.

Ključne riječi: profesija, profesionalizacija, ravnatelji, obrazovanje, Hrvatska 